\title{
Service Quality between e-Government Users and Administrators
}

\author{
Yu-Hsieh Sung ${ }^{\mathrm{a}}$, Su-Houn Liu ${ }^{\mathrm{b}}$, Hsiu-Li Liao ${ }^{\mathrm{b}}$ and Ching-Min Liu ${ }^{\mathrm{b}}$ \\ ${ }^{a}$ Research, Development and Evaluation Commission \\ E-mail: yhsung@rdec.gov.tw \\ ${ }^{\mathrm{b}}$ Chung Yuan Christian University \\ E-mail: \{vandy,wenlly\}@im.cycu.edu.tw;chingmin@mis.cycu.edu.tw
}

\section{Introduction}

Governments worldwide increasingly apply Internet technology to enhance and leverage their services to citizens. Taiwan has a strong ICT (information and communications technology) sector, and thus its government strives to improve its service quality and reduce operational costs by adopting advanced information technologies [1]. Taiwan has previously put many public services online through the MyEGov (www.gov.tw) portal built in 2002 by the Research, Development and Evaluation Commission (RDEC). The MyEGov portal is intended to be the entry point for all online public services, and is designed to provide a focal point for collecting government information and services. However, since different government agencies provide information and services independently on MyEGov, the scattered services cannot fulfill citizen demand for high quality e-Government service. Even though more than $80 \%$ of Taiwanese people are aware of this government website, only $8 \%$ of them ever use it to access services. Therefore, building quality services that encourage citizen uptake is becoming a major challenge for administrators of the MyEGov portal.

This study addresses the e-Government issue and explores the quality divide caused by perceived differences between users and administrators of the MyEGov portal. To understand how governments can successfully implement comprehensive government service relevant to citizens, a survey of both users and administrators is performed to review the MyEGov portal service quality. The investigation instrument is based on the conceptual model of service quality proposed by Parasuraman, Zeithaml and Berry [2,3]. This work develops a model to assess user intention of continuing to use the MyEGov portal by identifying major service quality variables of the website, and analyzes the impact of these variables on user intention of continued use of the MyEGov portal. This study also provides a valuable reference for governmental officials and practitioners to understand and improve website practice by identifying the major perceived differences (gaps) between the users and administrators of the e-Government portal that cause low website usage.

\section{Literature Review}

Parasuraman et al. presented the SERVQUAL model, which defines service quality as the relative perceptual distance between customer expectations and evaluations of service experiences and service quality. The SERVQUAL model has five dimensions, namely tangibles, reliability, responsiveness, assurance and empathy. The SERVQUAL model is widely employed to measure service quality in e-retailing [4-6], online auctions [7], e-banking [8], e-Government [9], online travel [10] and web-based services [11,12].

Traditional service quality might not be sufficient to build the e-service quality dimensions. Based on SERVQUAL model, Santouridis et al. investigated internet service quality and its impact on customer satis- 


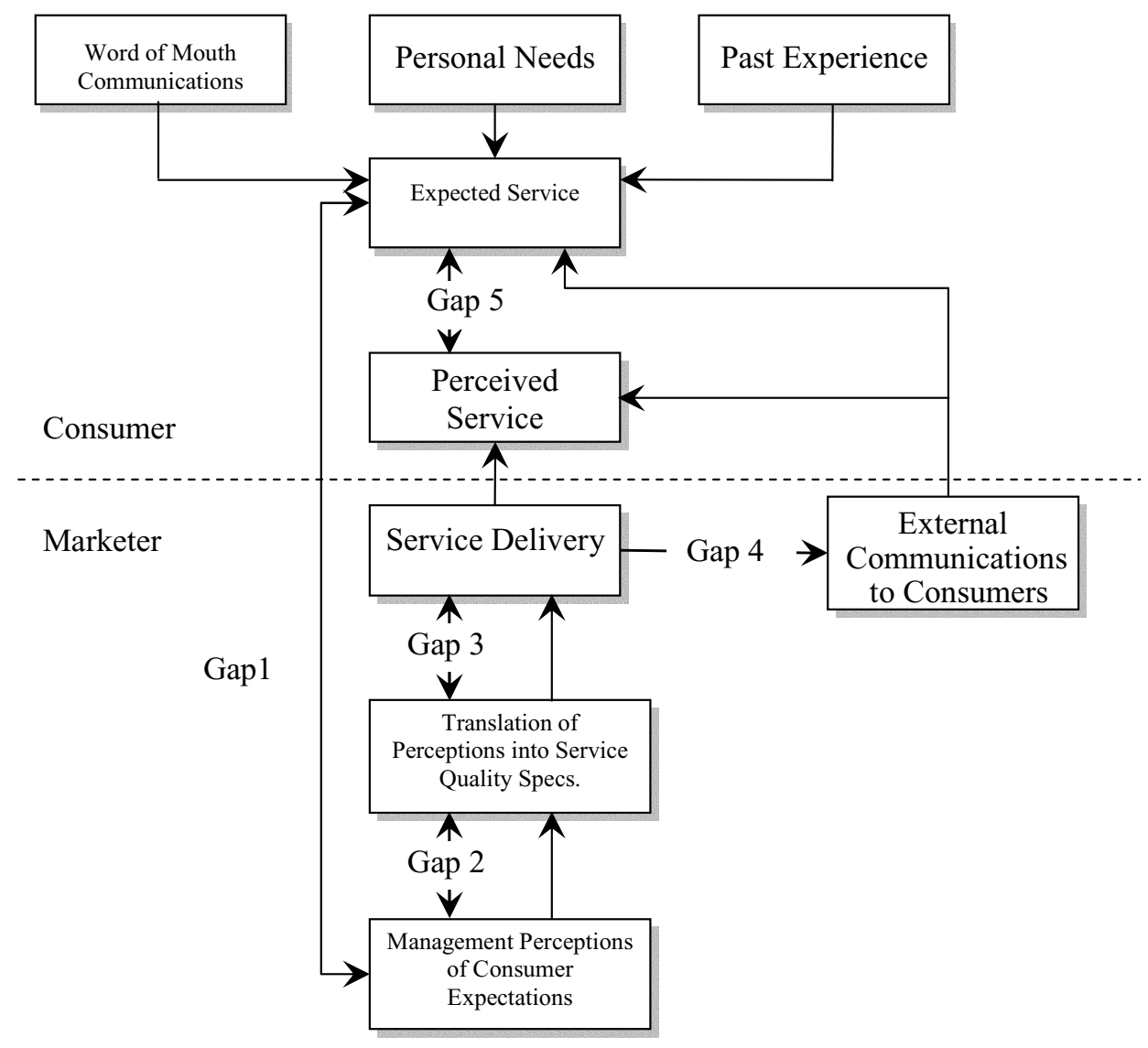

Fig. 1. Conceptual model of service quality.

faction in the internet banking context in Greece. All quality dimensions, namely assurance, quality of information, responsiveness, web assistance, empathy and reliability, were indicated to be antecedents of customer satisfaction, with reliability having the most significant impact. Jones and Leonard studied participants into their experience with $\mathrm{C} 2 \mathrm{C}$ e-commerce. Their findings revealed that SERVQUAL, which included reliability, responsiveness, assurance and empathy, all influence satisfaction in $\mathrm{C} 2 \mathrm{C}$ e-commerce. Reliability and responsiveness were found to affect $\mathrm{C} 2 \mathrm{C}$ e-commerce satisfaction, whereas they had no effect in the B2C study. Lee and Lin examined the relationship among e-service quality dimensions and overall service quality, customer satisfaction and purchase intentions of online shopping. The analytical results demonstrated that the dimensions of web site design, reliability, responsiveness and trust affected overall service quality and customer satisfaction. The personalization dimension was not significantly related to overall service quality or customer satisfaction.
Systems quality and information quality are viewed as important components of website quality. Separate measures of website information quality and website system quality are consistent with information systems quality models by DeLone and McLean [13] and Spreng et al. (1996). Wangpipatwong, S. et al. examined website quality, with the aim of improving the continued use of e-government portals by citizens of Thailand. They used multiple regression analysis to analyze three quality aspects, and found that system quality provided the greatest enhancement, followed by service quality and information quality. Hussein et al. [14] found that systems quality, information quality, perceived usefulness and user satisfaction are significantly correlated with the e-government system success dimensions in Malaysia. However, Jang et al. (2008) indicated that their community commitment was significantly affected by their community interaction and the rewards for their activities, but not by information quality and system quality. In the context of e-Government, few studies have examined the e-service quality dimen- 


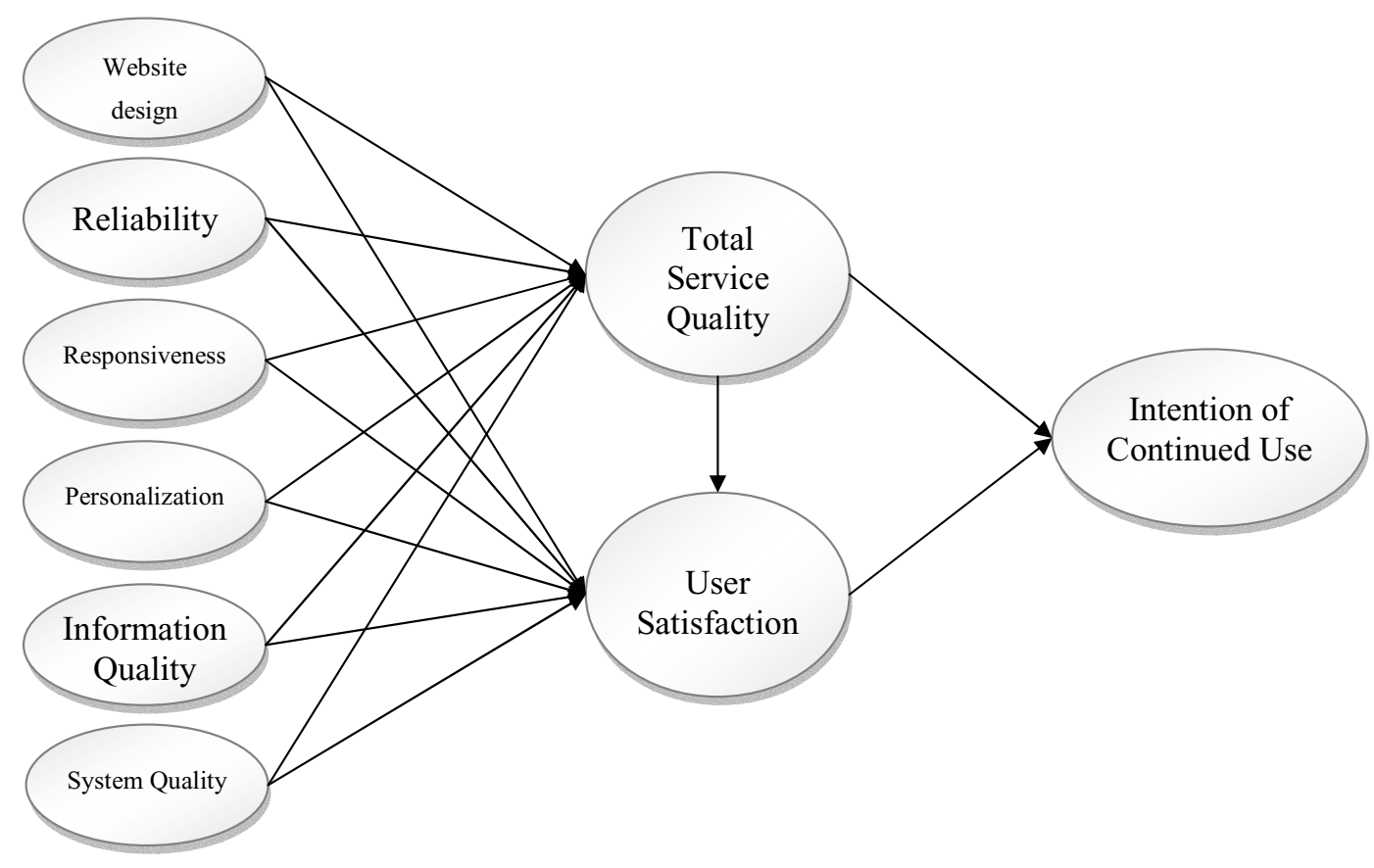

Fig. 2. The research model 1.

sions, system quality and information quality to predict overall service quality, user satisfaction and intention of continued use.

Parasuraman, Zeithaml, and Berry developed a service quality model, revealing that consumer's quality perceptions are influenced by a series of four distinct gaps (Gap $1 \sim$ Gap 4) occurring in organizations (Fig. 1). On the service provider's side, these gaps can inhibit the delivery of services that consumers perceive to be of high quality. Perceived service quality is defined in the model (Gap 5).

Gap 1: Difference between consumer expectations and management perceptions of consumer expectations

Gap 2: Difference between management perceptions of consumer expectations and service quality specifications

Gap 3: Difference between service quality specifications and the service actually delivered

Gap 4: Difference between service delivery and what is communicated about the service to consumers

Gap 5: Difference between consumer expectations and perceptions

This study attempts to adjust and verify the conceptual model of service quality to understand user perception of total service quality, user satisfaction and in- tention of continued use in the e-Government context. Figure 1.

\section{Research Methodology}

Figure 2 illustrates the proposed model drawn from the constructs of web-site design, reliability, responsiveness, personalization, information quality, system quality, total service quality, user satisfaction and intention of continued use, based on the constructs presented by Lee and Lin [15], and Delone and Mclean. The research model was empirically tested in this study. Table 1 defines the constructs, which are discussed below.

Based on the above literature review, this study proposes an e-service quality model for e-Government users. The hypotheses are formulated below to address the relationships of service quality, information quality, system quality, total service quality, user satisfaction and intention of continued use:

H1: Website design, reliability, responsiveness, personalization, information quality and system quality are positively related to total service quality.

H2: Website design, reliability, responsiveness, personalization, information quality and system 
Table 1

Research constructs and definitions

\begin{tabular}{|c|c|c|}
\hline Construct & Definition & References \\
\hline Website Design & The appeal to customers of the user interface design of e-government portal & {$[15,16]$} \\
\hline Reliability & $\begin{array}{l}\text { Degree to which the e-government portal fulfills orders correctly, delivers promptly and } \\
\text { keeps personal information secure }\end{array}$ & {$[15,17]$} \\
\hline Personalization & $\begin{array}{l}\text { Degree to which the e-government portal provides differentiated services to satisfy indi- } \\
\text { vidual needs }\end{array}$ & {$[15,19]$} \\
\hline System Quality & $\begin{array}{l}\text { Desired attributes of the information system itself (e.g. convenience of access, flexibility } \\
\text { of the system, integration of the system and response time) }\end{array}$ & {$[14,20]$} \\
\hline Total Service Quality & Customer perceptions of service quality provided by e-government portal. & {$[15,21]$} \\
\hline User satisfaction & Extent of user satisfaction with e-government portal. & {$[20,21]$} \\
\hline Intention of continued use & Likelihood of using e-government portal continuously & {$[21,22]$} \\
\hline
\end{tabular}

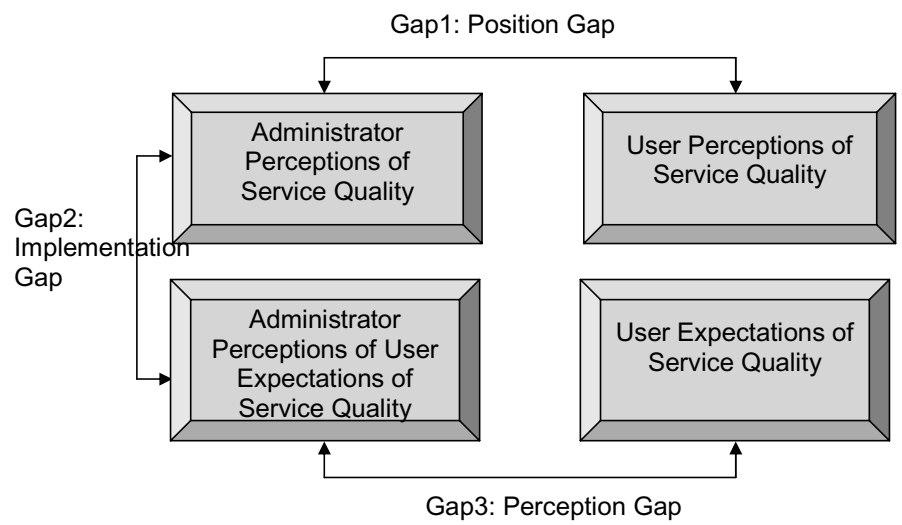

Fig. 3. Research model 2.

quality are positively related to user satisfaction.

H3: Total service quality is positively related to user satisfaction.

H4: Total service quality and user satisfaction are positively related to intention of continued use.

To explore perception and expectation differences between the users and administrators of MyEGov, this work identifies four service quality constructs to measure the differences (Fig. 3). Two constructs, "User Perceptions of Service Quality" and "User Expectations of Service Quality", are derived from user surveys that represent user perception and expectation of website service quality. The other two constructs, "Administrator Perceptions of Service Quality" and "Administrator Perceptions of User Expectations of Service Quality", are derived from administrator surveys of the administrators' perception and user expectation of website service quality. Gap1, the Position Gap, denotes the difference between "User Perceptions of Service Quality" and "Administrator Perceptions of Service Quali- ty". Gap2, the Implementation Gap, denotes the difference between "Administrator Perceptions of Service Quality" and "Administrator Perceptions of User Expectations of Service Quality". Gap3, the Perception Gap, represents the difference between "Administrator Perceptions of User Expectations of Service Quality" and "User Expectations of Service Quality".

Researchers asked MyEGov's users and administrators to respond to the questionnaire of this study. MyEGov users were randomly selected at 500 to respond the user survey questionnaire by e-mail. Among the questionnaires, 257 were returned and 241 were usable, representing a $48.2 \%$ response rate. Among the 241 usable questionnaires, 118 respondents were female $(49 \%)$ and 123 were male $(51 \%)$. The age of most subjects ranged from 21 to $35(74.7 \%)$. Most subjects were non-students (73.9\%) and had bachelor degrees (81\%). Researchers asked all eighteen MyEGov administrators to complete the administrator survey questionnaire. Sixteen returned and usable questionnaires represent a response rate of $88.9 \%$. 
Table 2

Construct reliabilities and average variance extracted

\begin{tabular}{lccc}
\hline Construct & $\begin{array}{c}\text { Composite } \\
\text { reliability (CR) }\end{array}$ & $\begin{array}{c}\text { Average variance } \\
\text { extracted (AVE) }\end{array}$ & Cronbach Alpha \\
\hline Website design (DES) & 0.923486 & 0.707401 & 0.895684 \\
Reliability (REL) & 0.928204 & 0.722327 & 0.903923 \\
Responsiveness (RES) & 0.929607 & 0.725513 & 0.904725 \\
Personalization (PER) & 0.937283 & 0.789040 & 0.910945 \\
Information quality (INF) & 0.913335 & 0.724906 & 0.873032 \\
System quality (SYS) & 0.905821 & 0.658081 & 0.870650 \\
Total service quality (TQS) & 0.941106 & 0.799824 & 0.913492 \\
User satisfaction (SAT) & 0.960451 & 0.858647 & 0.944440 \\
Intention of continued use (INT) & 0.957001 & 0.881231 & 0.930362 \\
\hline
\end{tabular}

Table 3

Correlations and Average Variance Extracted (AVE)

\begin{tabular}{lccccccccc}
\hline & DES & REL & RES & PER & INF & SYS & TQS & SAT & INT \\
\hline DES & $\mathbf{0 . 8 4 1}$ & & & & & & & & \\
REL & 0.531 & $\mathbf{0 . 8 5 0}$ & & & & & & & \\
RES & 0.680 & 0.758 & $\mathbf{0 . 8 5 2}$ & & & & & & \\
PER & 0.625 & 0.630 & 0.765 & $\mathbf{0 . 8 8 8}$ & & & & & \\
INF & 0.676 & 0.666 & 0.732 & 0.751 & $\mathbf{0 . 8 5 1}$ & & & & \\
SYS & 0.679 & 0.705 & 0.798 & 0.731 & 0.811 & $\mathbf{0 . 8 1 1}$ & & & \\
TQS & 0.681 & 0.560 & 0.656 & 0.582 & 0.732 & 0.718 & $\mathbf{0 . 8 9 4}$ & & \\
SAT & 0.764 & 0.664 & 0.783 & 0.707 & 0.783 & 0.798 & 0.846 & $\mathbf{0 . 9 2 7}$ & \\
INT & 0.620 & 0.537 & 0.618 & 0.491 & 0.603 & 0.630 & 0.776 & 0.786 & $\mathbf{0 . 9 3 9}$ \\
\hline
\end{tabular}

Diagonal bolded elements are the square root of AVE.

\section{Analysis and Results}

The research model was measured with the partial least squares (PLS) structural modeling analysis approach. PLS is appropriate for predicting highly complex [23] models, and maximizing the variance explained for the constructs in a model [24]. Table 2 presents the composite reliability (CR), average variance extracted (AVE), and Cronbach's $\alpha$. All reliability measures were 0.7 or above. The pha-level of the sample demonstrates a reasonable level of reliability, and thus adequate internal consistency. Table 3 shows the square root of AVE and intercorrelations of each variable, ranging from 0.491 to 0.846 . Convergent validity of the instrument is appropriate when the constructs have an average variance extracted (AVE) of at least 0.5 [25]. The AVE for each construct is larger than the correlation between that construct and other constructs in the model.

Website design ( $\beta=0.282, p<0.01)$, personalization $(\beta=-0.118, p<0.1)$, information quality $(\beta=$ $0.354, p<0.01)$ and system quality $(\beta=0.256, p<$ $0.01)$ significantly affect total service quality $\left(\mathrm{R}^{2}=\right.$ $0.627)$. Website design $(\beta=0.184, p<0.01)$, Responsiveness $(\beta=0.159, p<0.05)$ and system quality $(\beta=0.126, p<0.05)$, significantly influence user satisfaction $\left(\mathrm{R}^{2}=0.841\right)$. Total service quality $(\beta=$
Table 4

Mann-Whitney U test - Gap1: Position Gap

\begin{tabular}{lccc}
\hline Construct & Mann-Whitney U & Z-test & P-value \\
\hline Website design & 1340.00 & -2.047 & $0.041^{*}$ \\
Reliability & 999.00 & -3.234 & $0.001^{*}$ \\
Responsiveness & 1153.50 & -2.696 & $0.007^{*}$ \\
Personality & 953.50 & -3.394 & $0.001^{*}$ \\
Information quality & 1410.50 & -1.806 & 0.071 \\
System quality & 1398.00 & -1.841 & 0.066 \\
\hline
\end{tabular}

$* p<0.05$.

$0.390, p<0.01)$ and user satisfaction $(\beta=0.457$, $p<0.01$ ) have significant, direct effect on Intention of continued use $\left(\mathrm{R}^{2}=0.661\right)$ (Fig. 4).

Differences in perceptions and expectation exist between MyEGov's users and administrators. This investigation applies the Mann-Whitney $\mathrm{U}$ test to test the existence of Gap1, Gap2 and Gap3. Gap1: Position Gap represents the differences between "User Perceptions of Service Quality" and "Administrator Perceptions of Service Quality". Website design, reliability, responsiveness and personalization were different between MyEGov's users and administrators (Table 4). Gap2: Implementation Gap represents the difference between "Administrator Perceptions of Service Quality" and "Administrator Perceptions of User Expectations of Service Quality". Website design, reliability, responsiveness, information quality and system quality had significant differences (Table 5). Gap3: Perception 


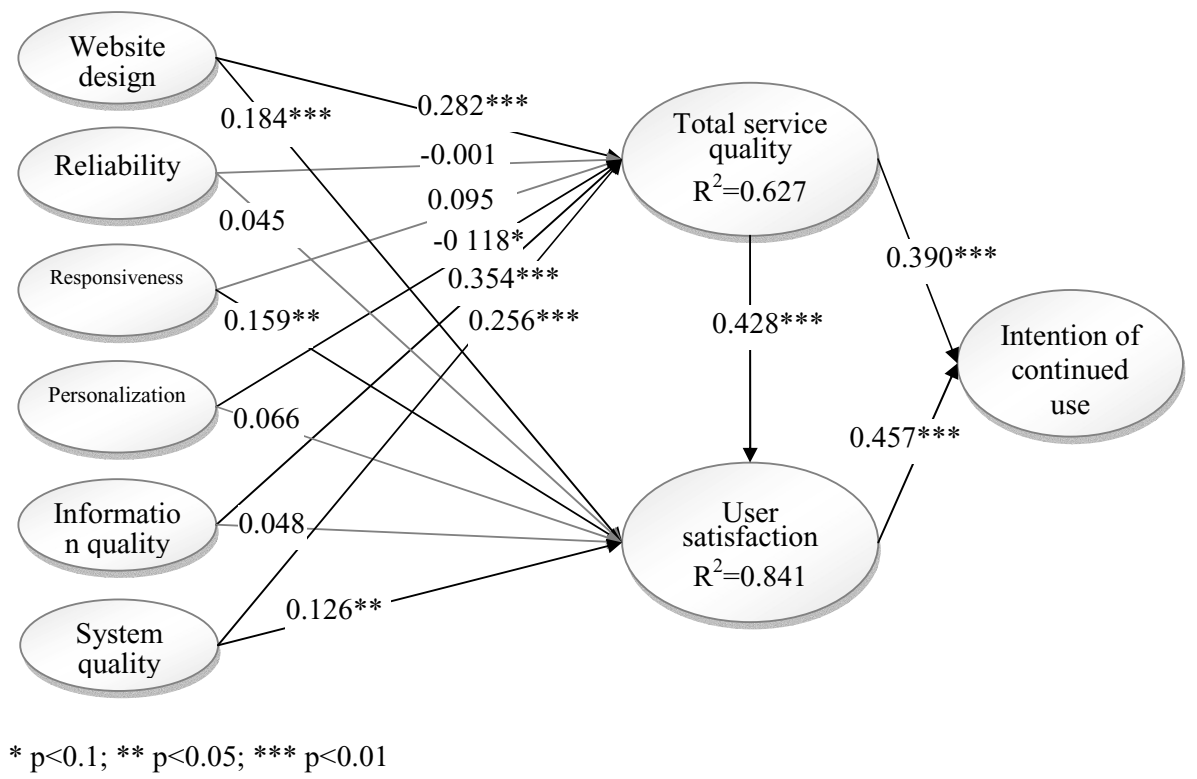

Fig. 4. Research model results. $* p<0.1 ; * * p<0.05$; *** $p<0.01$.

Table 5

Mann-Whitney U test - Gap2: Implementation Gap

\begin{tabular}{lccl}
\hline Construct & Mann-Whitney U & Z-test & P-value \\
\hline Website design & 58.00 & -2.653 & $0.008^{*}$ \\
Reliability & 45.00 & -3.145 & $0.002^{*}$ \\
Responsiveness & 66.00 & -2.351 & $0.019^{*}$ \\
Personality & 78.50 & -1.879 & 0.060 \\
Information quality & 52.50 & -2.867 & $0.004^{*}$ \\
System quality & 69.00 & -2.237 & $0.025^{*}$ \\
\hline
\end{tabular}

$* p<0.05$.

Gap represents the difference between "Administrator Perceptions of User Expectations of Service Quality" and "User Expectations of Service Quality". Website design, reliability, responsiveness, personalization, information quality and system quality significantly differed between administrator perceptions and user expectations (Table 6).

\section{Conclusions and Management Implications}

System quality is widely accepted as critical for user willingness to reuse an information system. Results of this study corroborate all three hypotheses about the relationship of Total Service Quality, User Satisfaction and Intention to Continued Usage. In this study, both Total Service Quality and User Satisfaction positively relate to user's intention to continue use of MyEGov. Empirical findings from this work also indicate that the causal relationship between Total Service Quality
Table 6

Mann-Whitney U test - Gap3: Perception Gap

\begin{tabular}{lccc}
\hline Construct & Mann-Whitney U & Z-test & P-value \\
\hline Website design & 344.00 & -5.513 & $0.000^{*}$ \\
Reliability & 111.50 & -6.321 & $0.000^{*}$ \\
Responsiveness & 406.00 & -5.297 & $0.000^{*}$ \\
Personality & 416.00 & -5.264 & $0.000^{*}$ \\
Information quality & 398.50 & -5.335 & $0.000^{*}$ \\
System quality & 298.00 & -5.661 & $0.000^{*}$ \\
\hline
\end{tabular}

$* p<0.05$.

and the outcome variable (User Satisfaction) are as predicted in the previous literature.

Many quality factors (Website design, Reliability, Responsiveness, Personalization, Information Quality, and System Quality) affect a website's total service quality and user satisfaction in general, according to existing IS-related literature. However, this study found that for e-government portal usage, main system quality variables may not relate to each other as found in previous studies. Empirical findings from this research reveal that Website Design, Personalization, Information Quality, System Quality have significant relationships with Total Service Quality. Among them, Personalization has a negative relationship with user perceptions of the website's Total Service Quality.

We believe that the relationships between various quality variables and Total Service Quality may indicate that most users use MyEGov simply as a government information retrieval website. In other words, users visit MyEGov to browse information of interest 
Table 7

Service Gaps of MyEGov

\begin{tabular}{|c|c|c|c|}
\hline $\begin{array}{l}\text { User Perceptions } \\
\text { of Service Quality }\end{array}$ & $\begin{array}{l}\text { Administrator } \\
\text { Perceptions } \\
\text { of Service Quality }\end{array}$ & $\begin{array}{l}\text { Administrator } \\
\text { Perceptions of } \\
\text { User Expectations } \\
\text { of Service Quality }\end{array}$ & $\begin{array}{l}\text { User Expectations } \\
\text { of Service Quality }\end{array}$ \\
\hline $\begin{array}{l}\text { Website design } \\
\text { Information Quality } \\
\text { System Quality } \\
\text { Responsiveness } \\
\text { Reliability } \\
\text { Personalization }\end{array}$ & $\begin{array}{l}\text { Reliability } \\
\text { Responsiveness } \\
\text { Information Quality } \\
\text { Website design } \\
\text { Personalization } \\
\text { System Quality }\end{array}$ & $\begin{array}{l}\text { Reliability } \\
\text { Information Quality } \\
\text { Website design } \\
\text { Responsiveness } \\
\text { System Quality } \\
\text { Personalization }\end{array}$ & $\begin{array}{l}\text { Website design } \\
\text { Information Quality } \\
\text { System Quality } \\
\text { Reliability } \\
\text { Responsiveness } \\
\text {-Personalization }\end{array}$ \\
\hline
\end{tabular}

to them, rather than to conduct online transactions with government offices. Thus, the reliability and Responsiveness factors of the website are irrelevant for these users. Personalization of the portal may be very important for users wanting to conduct online transactions with government. However, personalization may limit the information that users who simply want to browse various government-related information and thus has a negative relationship with user perceptions of the website's Total Service Quality. The quality derived from a good website design, information and system quality may be more important to these users.

For User Satisfaction of the e-government portal, findings of this study indicate that Website Design, Responsiveness and System Quality have significant positive impacts. Among these, Website Design is the most critical factor. These relationships appear to indicate that most users consider MyEGov as an information broker instead of an information provider. Namely, even though users recognize that Information Quality has a positive impact on their service quality perceptions, they do not recognize MyEGov as being responsible for good or poor quality website information. They recognize MyEGov is responsible for the operation and system side only. Therefore, quality variables related to the operation and system of MyEGov also relate to User Satisfaction.

According to the understanding that users regard MyEGov as an Information Broker and use it merely to retrieve government information, whether the website administrators implement MyEGov have the same perception should be further investigated. Analytical results demonstrate that they did not recognize this fact. This study found that all the differences between "User Perceptions of Service Quality”, "Administrator Perceptions of Service Quality", "Administrator Perceptions of User Expectations of Service Quality" and "Us- er Expectations of Service Quality" were significant. For instance, the administrators recognized Reliability as the most important factor both in their perceptions of user expectations of service quality and on MyEGov's service quality. However, users did not think MyEGov was reliable (it ranked No. 5 on the list of the "User Perceptions of Service Quality" column); they also did not think that the reliability of MyEGov was very important (it ranked No. 4 on the list of the "User Expectations of Service Quality" column).

We believe that these results have important implications for administrators and their management of MyEGov. The administrators of MyEGov want to construct an integrated government service access point (a Virtual Government) on the web. However, from the user's point of view, they browse MyEGov looking for government information, but not services. Understanding the nature and determinants of users' intention to continued usage is a necessary and critical starting point in developing and implementing an e-government portal service. Administrators who believe that they are running an integrated website for government service, while their users do not believe and expect such, cannot expect high user intention to continue using MyEGov. Accordingly, this research recommends that administrators focus on eliminating the gaps between their's and user's perceptions of MyEGov. This can be performed by either positioning the website in a more practical position (provide government information instead of services), or by educating their users to trust and accept online government service on their websites.

\section{References}

[1] Y.-E. Sung, Research and Implementation of e-Government, Sun Yun Suan Academic Foundation, 2007. 
[2] A. Parasuraman, V.A. Zeithaml and L.L. Berry, A Conceptual Model of Service Quality and Its Implications for Future Research, Journal of Marketing 49 (1985), 41-50.

[3] A. Parasuraman, V.A. Zeithaml and L.L. Berry, SERVQUAL: a multiple item scale for measuring customer perceptions of service quality, Journal of Retailing 64(1) (1988), 12-40.

[4] S. Barnes and R. Vidgen, An Integrative Approach to the Assessment of E-commerce Quality, Journal of Electronic Commerce Research 3(2) (2002), 114-127.

[5] S.F. Lin and G.G. Lee, A Study of Service Quality Evaluation Model for Virtual Knowledge Communities, EC Research 4(2) (2006), 221-234.

[6] S.I. Swaid and R.T. Wigand, Measuring the Quality of EService: Scale Development And Initial Validation, Journal of Electronic Commerce Research 10(1) (2009), 13-28.

[7] K. Jones and L.N.K. Leonard, Consumer-to-Consumer Electronic Commerce: A Distinct Research Stream, Journal of Electronic Commerce in Organizations 5(4) (2007), 39-55.

[8] I. Santouridis, P. Trivellas and P. Reklitis, Internet Service Quality and Customer Satisfaction: Examining Internet Banking in Greece, Total Quality Management \& Business Excellence 20(2) (2009), 223-237.

[9] S. Wangpipatwong, W. Chutimaskul and B. Papasratorn, Quality En Quality Enhancing the Continued Use of E-Government Web Sites: Evidence from E-Citizens of Thailand. International Journal of Electronic Government Research, International Journal of Electronic Government Research 5(1) (2009), 19-35.

[10] A. Van Riel, J. Semeijn and P. Pauwels, Online Travel Service Quality: the Role of Pre-Transaction Services, Total Quality Management 15(4) (2004), 475-493.

[11] Y.F. Kuo, A Study on Service Quality of Virtual Community Web Sites, Total Quality Management 14(4) (2003), 461-473.

[12] T. Kuo, L.Y. Lu, C.H. Huang and G.C. Wu, Measuring Users' Perceived Portal Service Quality: An Empirical Study, Total Quality Management \& Business Excellence 16(3) (2005), 309-324.

[13] W.H. DeLone and E.R. McLean, Information system success: the quest for the dependent variable, Information System Research 6 (1992), 60-95.

[14] R. Hussein, N.S.A. Karim and M.H. Selamat, The Impact of
Technological Factors on Information Systems Success in thex Electronic-Government Context, Business Process Management Journal 13(5) (2007), 613-628.

[15] G.G. Lee and H.F. Lin, Customer Perceptions Of E-service Quality In Online Shopping, International Journal of Retail and Distribution Management 33(2) (2005), 161-176.

[16] J. Santos, E-service Quality: A Model of Virtual Service Quality Dimensions, Managing Service Quality 13(3) (2003), 233-246.

[17] J. Kim and J. Lee, Critical Design Factors for Successful E-commerce Systems, Behaviour \& Information Technology 21(3) (2002), 185-199.

[18] M. Wang, Assessment of E-Service Quality via E-Satisfaction in E-Commerce Globalization, The Electronic Journal on Information Systems in Developing Countries 11(10) (2003), $1-4$.

[19] M. Wolfinbarger and M.G. Gilly, eTailQ: dimensionalizing, measuring and predicting etail quality, Journal of Retailing 79(3) (2003), 183-198.

[20] J. Iivari, An empirical test of the DeLone-McLean model of information system success, ACM SIGMIS Database 36(2) (2005), 8-27.

[21] F.X. Zhu, W. Wymer and I. Chen, IT-based services and service quality in consumer banking, International Journal of Service Industry Management 13(1) (2002), 69-90.

[22] A. Parasuraman, V.A. Zeithaml and A. Malhotra, E-S-QUAL: A Multiple-Item Scale for Assessing Electronic Service Quality, Journal of Service Research 7(3) (2005), 213-233.

[23] D.W. Barclay, C.A. Higgins and R. Thompson, The Partial Least Squares (PLS) approach to causal modeling: Personal computer adoption and use as an illustration, Tech Stud 2(2) (1995), 285-309.

[24] C.R. Plouffe, J.S. Hulland and M. Vandenbosch, Research report: richness versus parsimony in modeling technology adoption decisions-understanding merchant adoption of a smart card-based payment system, Information Systems Research 12(2) (2001), 208-222.

[25] C. Fornell and D.F. Larcker, Evaluating structural equation models with unobservable variables and measurement error, Journal Marketing Research 18 (1981), 39-50. 